\title{
Decolonizing the teXtBOOK descolonizar el libro de texto: \\ Open Educational Resources in Spanish ReCursos educativos ABiertos
}

\section{Vicki Gruzynski \\ Worcester State University}




\section{What are Open Educational Resources?}

From UNESCO:

Open Educational Resources are teaching, learning or research materials that are in the public domain or released with an intellectual property license that allows for free use, adaptation, and distribution.

http://www. unesco.org/new/en/communication-and-information/a ccess-to-knowledge/open-educational-resources/ 


\section{THE FIVE RS}

\section{Retain}

"Open" permissions are typically defined in

Reuse

Revise

Remix

Redistribute terms of the " $5 \mathrm{R}$ ' $s$ ":

users are free to

Retain, Reuse, Revise, Remix and Redistribute these educational materials." 
Creative Commons Licenses

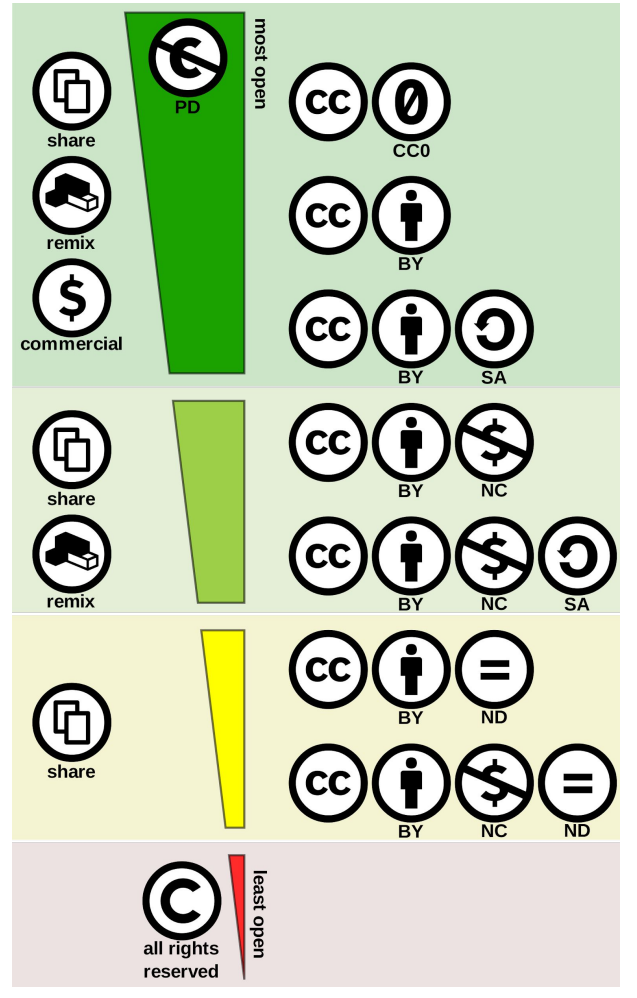

FIGURE 2: THE SIX VARIATIONS OF THE CC LICENCES

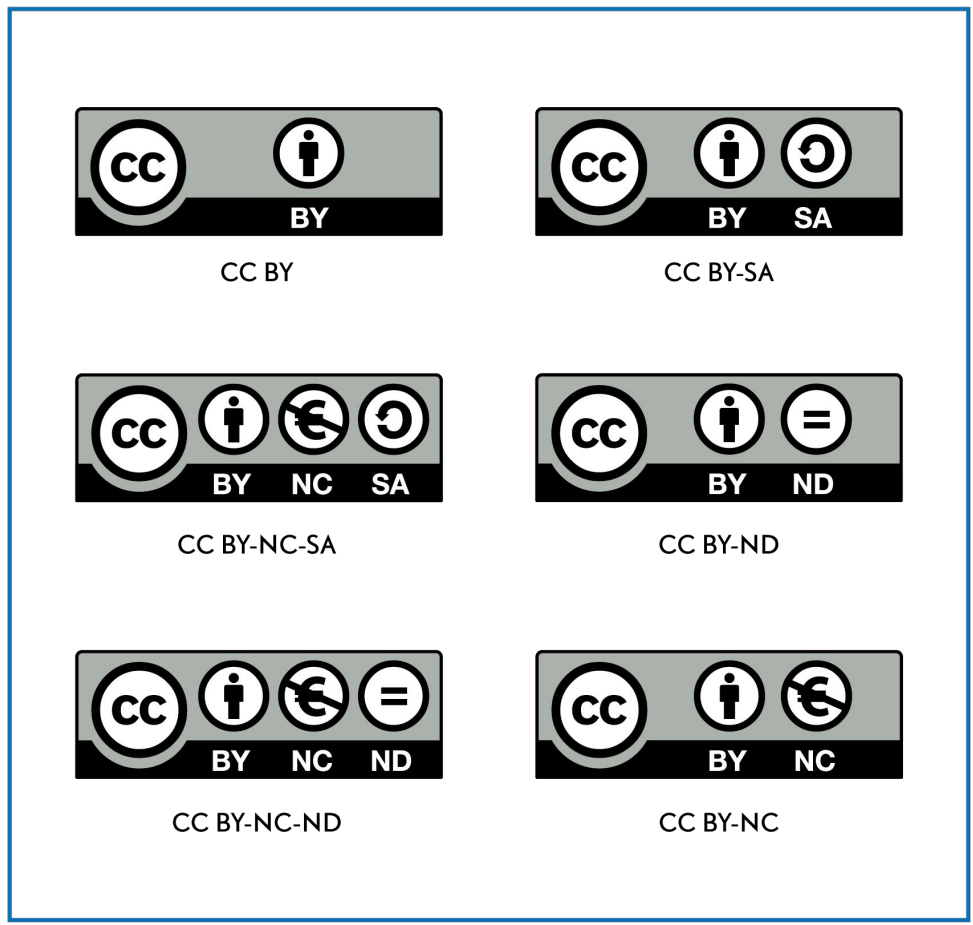




\section{OER: NOT JUST TEXTBOOKS}

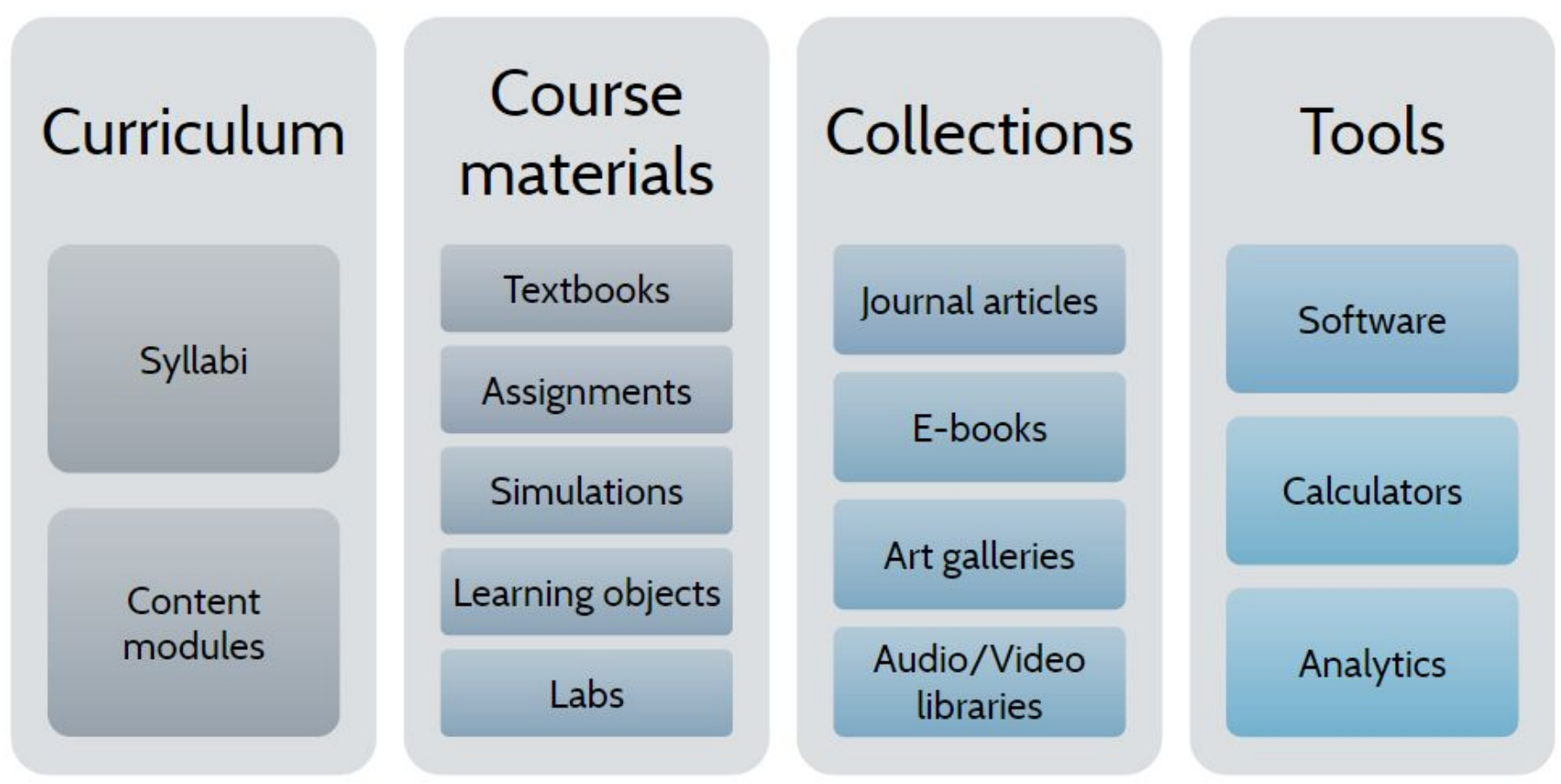

Image courtesy of Jeremy Smith and Marilyn Billings, UMass, Amherst 


\section{Misconceptions OF OER}

- Free versus open

- Not just textbooks

- You get what you pay for

- Students expect textbooks

- It takes too much time to implement

- Loss of intellectual freedom

- Just moving everything online 


\section{WHY OER?}

- Lowers/eliminates cost

- Frees faculty and students from the constraints of mass-produced textbooks

- Did I mention cost?

- More/better access to course materials (before, during, AFTER)

- Same or better quality as commercially produced materials

- Others can build upon faculty and student work 


\section{WHY OER?}

- Lowers/eliminates cost

- Frees faculty and students from the constraints of mass-produced textbooks

- Did I mention cost?

- More/better access to course materials (before, during, AFTER)

- Same or better quality as commercially produced materials

- Others can build upon faculty and student work 


\section{WHY US?}

Librarians are trained to find and evaluate information - a useful skill

The library is the intellectual hub or nexus of campus this way, the effort doesn't only live in certain departments and the entire campus is supported in their efforts

When students don't buy their books, they often come to library to help fill in the gaps 


\section{WHAT'S HAPPENING TO SUPPORT OER?}

Congress funded a \$5 million open textbook grant program in the FY18 omnibus appropriations bill

https://sparcopen.org/what-we-do/active-policy/

Open policy milestones in the USA and Brazil

https://sparcopen.org/news/2018/open-licensing-policy-milest ones-u-s-brazil/ 


\section{WHAT'S HAPPENING TO SUPPORT OER?}

Mason OER Metafinder

https://mason.deepwebaccess.com/mason MasonLibrariesOpenEdu cationResources 5f4/desktop/en/search.html

State Initiatives

Oregon, California, Virginia ... others!

Campus Initiatives

University of Massachusetts Amherst 


\section{WORCESTER StATE UNIVERSITY}

\section{Worcastre}

UNIVERSITY

Worcester State University Library / LibGuides / Open Educational Resources Initiative (OERI) / Home

Open Educational Resources Initiative (OERI): Home

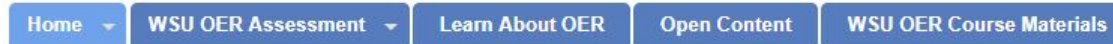

\section{Welcome!}

The WSU Library is committed to educational innovation and student-centered best practices. In Fall 2016, we launched the WSU Library Open Educational Resources Initiative (OERI) to foster instructional effectiveness while lowering costs for students. From the Spring 2017 to the Spring 2018 semester, we awarded twenty six $\$ 1,000$ mini-grants to faculty who redesigned their courses using open educational resources. To date, we have saved students over $\$ 55,000$ ! The Initiative continues with our fourth call for applications for mini-grants for courses scheduled to run during the Fall 2018 semester

The Application for Fall 2018 courses is closed.

- Learn about Open Educational Resources

- Explore Open Content Repositories

- Learn about previous OERI mini-grants: Previous Round (Spring 2017 Courses), Previous Round (Fall 2017 Courses), Previous Round (Spring 2018)

The WSU Library Open Educational Resources Initiative has been made possible through the generous support of Reach Out for Schools, the WSU Provost's Office, the WSU Graduate School, and the WSU Library.

\section{Reach Out forSCHOOLS}



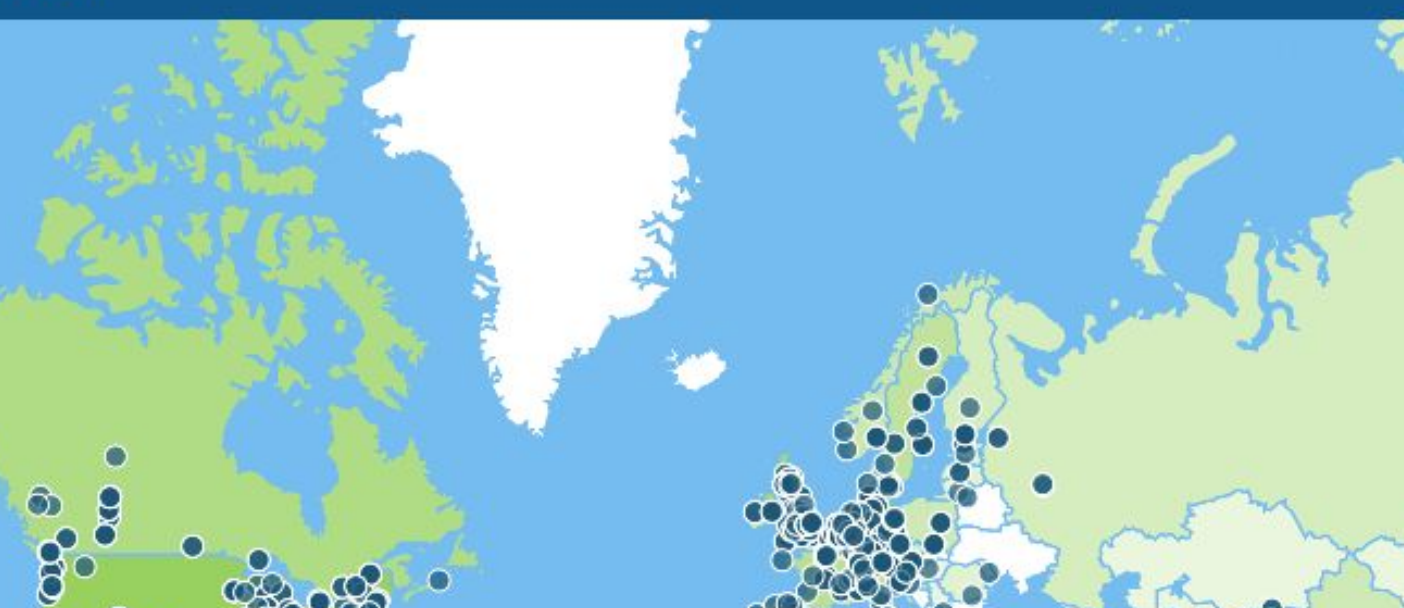

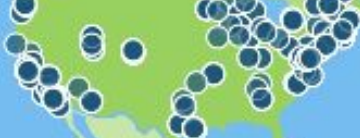

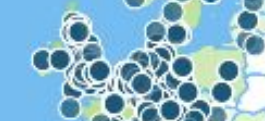

$80^{\circ}$
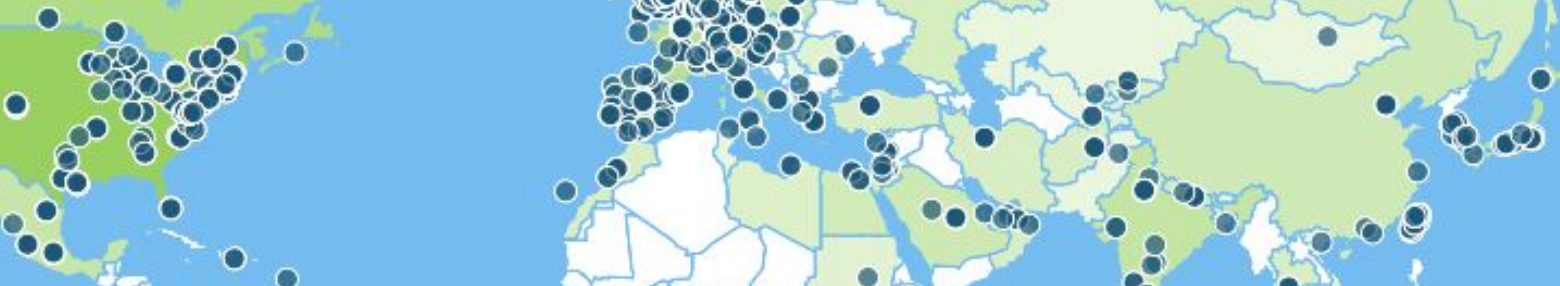

o

0.0.

cै। है।

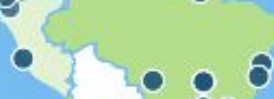

$\ln ^{2} a^{\circ}$

$6 \cdot 2$

$+-0 \quad 0 \quad$ Entries per Country

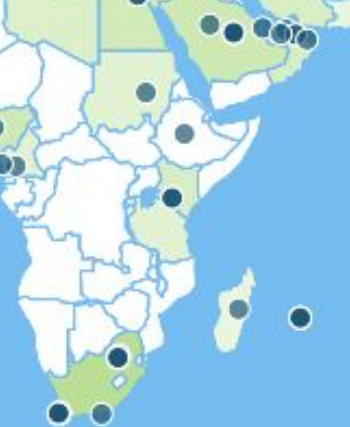

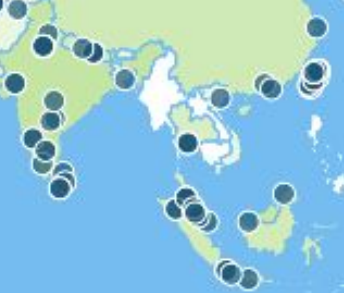

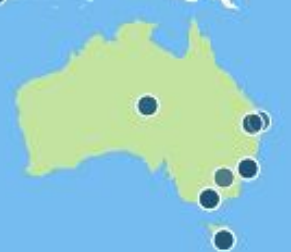




\section{EN ESPAÑOL}

Español abierto

http://espanolabierto.org/

OER Commons example (from a WSU colleague!)

https://www.oercommons.org/courses/open-educational-resource s-for-spanish-classes-advanced-spanish-composition-ii

Humboldt State University

http://libguides.humboldt.edu/openedu/span

Concordia University

http://libguides.cu-portland.edu/OER/spanish 


\section{EM FIM}

OER is great, especially for students

Build a community

Support from administration is key

(C) (i) (3)(2)

Reach out any time! I love talking about OER.

Decolonizing the

Textbook by Vicki

Gruzynski is

vgruzynski [a] worcester.edu

licensed under a

Creative Commons

Attribution-NonCom

mercial-ShareAlike

4.0 International

License. 